\title{
The materials to determine the eastern range border of acidophilous oak forest Calamagrostio arundinaceae-Quercetum petraeae in Poland - two new stands of the association in the southern part of Mazovian Voivodeship
}

\author{
Piotr T. Zaniewski, Wojciech Ciurzycki, Katarzyna Marciszewska \\ Warsaw University of Life Sciences - SGGW, Institute of Forest Sciences, Department of Forest Botany, \\ 159 Nowoursynowska St., 02-776 Warsaw, Poland \\ Tel. +48 22 5938028, e-mail: piotr.zaniewski@wl.sggw.pl
}

\begin{abstract}
Acidophilous oak forests Calamagrostio arundinaceae-Quercetum petraeae (Hartm. 1934 Scam. et Pass. 1959) are mostly known from the western part of Poland, while its eastern border has not been determined accurately. In order to address this issue, we performed a phytosociological analysis of two newly identified stands of acidophilous oak forest located in the southern part of the Mazovian Voivodeship near Kiedrzyn (vicinity of Nowe Miasto nad Pilicą) and Mikówka (vicinity of Białobrzegi). For comparison, we also examined the distribution of known patches in the region (Łódź and Mazovian Voivodeships) against this association's background of the eastern range border.

Within the identified sites, a total of 10 phytosociological relevés were taken and soil samples were collected from a depth of $10 \mathrm{~cm}$. The content of organic matter, soil $\mathrm{pH}$ and sieving analysis were performed in the laboratory. The phytosociological material was ordered and numerically classified which gave two groups of relevés: typical for this association (seven relevés) and a degenerated form (three relevés), which has an increased share of pine in the stand. All our relevés were similar to acidophilous oak forests from the Wielkopolska region and thus different from oak-pine forests of eastern Poland. Habitat conditions of the patches and the bonitation of oak were analogous to patches of this association from other parts of Poland. Furthermore, the sites we studied are located between known locations from the Bolimowska and Kozienicka Forests and are therefore connecting these two previously known areas of occurrence. This indicates that the range of the CalamagrostioQuercetum association is at least a few dozen kilometers wider in this part of the country than the assumed range.
\end{abstract}

Keywords: Quercetea robori-petraeae, central Poland, sessile oak, pinetization, degeneration forms

\section{Introduction}

The acidophilous sessile oak forest (acidophilous central European oak forest, central European lowland oak forest) Calamagrostio arundinaceae-Quercetum petreae (Hartm. 1934 Scam. et Pass. 1959) was described in Germany (Hartmann 1934; Scamoni 1961) and later in western Poland (Fabiszewski, Faliński 1964). It occurs mainly in areas lacking beeches. The centre of its occurrence in Poland is in the southwestern and western part of the country (Matuszkiewicz 1988; Kasprowicz 2010). Among the associations of the Quercetea robori-petreae class, it is most similar to the mixed coniferous forests of the Dicrano-Pinion alliance within the Vaccinio -Piceetea class. In central Poland, there is a wide transitional belt between these communities; hence, it has been difficult to delimit their ranges for years (Matuszkiewicz 1988). The syntaxonomic separation of acidophilous oak and mixed coniferous forests in central Europe, as well as the distinction of their basic associations has been attempted for decades (Matuszkiewicz, Matuszkiewicz 1996; Kasprowicz 2010).

The basic component of the acidophilous oak forest is the sessile oak Quercus petraea, possibly with a small admixture of Scots pine Pinus sylvestris L. in the stand. The shrub layer is distinguished by the presence of: alder buckthorn Frangula alnus Mill., rowan Sorbus aucuparia L. or hazel Corylus avellana $\mathrm{L}$. The undergrowth is characterized by a significant share of general forest mesotrophic species, such as: the bunchgrass Calamagrostis arundinacea (L.) Roth, wavy hair-grass De-

Received: 26.11.2019 r., accepted after revision: 19.02.2020 r. 
schampsia flexuosa (L.) Trin., common cow-wheat Melampyrum pratense L., bracken Pteridium aquilinum (L.) Kuhn, May lily Maianthemum bifolium (L.) F. W. Schmidt, and a small share of species of the Vaccinio-Piceetea class, mainly bilberry Vaccinium myrtillus L. and lingonberry Vaccinium vitisidaea L., and the presence of species associated with acidophilous oak forests in general, especially the hawkweeds Hieracium spp. In addition, some of deciduous forests species sporadically grow there, such as mountain melick Melica nutans L. and early dogviolet Viola reichenbachiana Jord. ex Boreau. Pill sedge Carex pilulifera L. and sheep fescue Festuca ovina L., regularly appear in this community, distinguishing it from other acidophilous oak forest associations. The moss layer of the acidophilous oak forest is poorly developed, most often with broom forkmoss Dicranum scoparium Hedw., hypnum moss Hypnum cupressiforme Hedw. or bank haircap Polytrichastrum formosum (Hedw.) G. L. Sm. (Matuszkiewicz 1988, 2001; Matuszkiewicz 2008; Kasprowicz 2010; Matuszkiewicz et al. 2012). In the Wielkopolska region, the acidophilous oak forest is primarily associated with the forest habitat types defined as fresh mixed coniferous forests, fresh mixed deciduous forests and poorer fresh forests (Lasota et al. 2005). It occurs mainly on sandy (loose and weak loamy) formations (Lasota et al. 2005; Rutkowski, Maciejewska-Rutkowska 2007).

The Calamagrostio arundinaceae-Quercetum petraeae association has been recorded in many locations in southern, southwestern and western Poland (e.g., Krotoska, Piotrowska 1962; Fabiszewski, Faliński 1964; Kamionka 1971; Kuczyńska 1973; Celiński, Wika 1978; Olaczek 1986; Matuszkiewicz 1988; Cabała 1990; Hereźniak 1993; Kwiatkowski 1995; Brzeg et al. 2001; Greń, Wika 2009; Kurowski 2009; Kasprowicz 2010) and probably in the Świętokrzyskie Mountains (Matuszkiewicz 2001; Przemyski 2011 pers. comm. in Koba 2012). Data on acidophilous oak forests in the Wielkopolska region were collected by Brzeg et al. (2001), followed by Kasprowicz (2010). In this region, the need to extend the boundary of the association to the north was demonstrated (Kasprowicz 2010). Slightly later, patches of Calamagrostio-Quercetum were found in central Poland. This community was found in Łódź Voivodeship: in the eastern part of the Kolska Basin (Olaczek 1972), Załęczański Landscape Park (Olaczek 1986), Łagiewnicki Forest in Łódź and the nearby Parowy Janinowskie Reserve (Kurowski 1998; Andrzejewski, Kurowski 2001; Socha 2011; Kurowski, Andrzejewski 2013), the Dąbrowa Reserve in Marianek (Kiedrzyński, Kurowski 2013), the Diabła Góra Reserve (BULiGL 2017) and in the western part of the Bolimowska Forest (Jakubowska-Gabara 1999). In the Mazovian Voivodeship, the acidophilous oak forest was recorded in the eastern part of Bolimowska Forest (Jakubowska-Gabara 1999), and then in the Kozienicka Forest (Koba 2012, 2013). The eastern border of the range of Calamagrostio arundina-
ceae-Quercetum is difficult to establish, due to the existence of transition forms to Querco roboris-Pinetum and the small amount of available phytosociological data. For this reason, it is 'provisional' (Matuszkiewicz 1988; Matuszkiewicz, Matuszkiewicz 1996; Matuszkiewicz 2008). There are also reports of the occurrence of acidophilous oak forests in Ukraine (e.g., Matuszkiewicz et al. 2012; Goncharenko, Yatsenko 2020).

During the field work in the south of the Mazovian Voivodeship, two sites of the Calamagrostio-Quercetum association were found in the vicinity of the villages of Kiedrzyn (near Nowe Miasto nad Pilicą) and Mikówka (near Białobrzegi). These patches occur outside the 'provisional' boundary of the association's range adopted by Matuszkiewicz (Matuszkiewicz 1988; Matuszkiewicz, Matuszkiewicz 1996). They constitute a spatial link between the known border sites in Kozienicka Forest (Koba 2012, 2013) and the sites in the Łódź Voivodeship at the edge of their range. The aim of this study was to summarize the distribution of the known Calamagrostio-Quercetum sites in the area of the eastern border of its range (the Łódź and Mazovian Voivodeships) and to document two newly recognized sites of the association.

\section{Materials and methods}

The field work was conducted in the 2017 (Kiedrzyn) and 2019 (Mikówka) vegetation seasons. Phytosociological relevés of $400 \mathrm{~m}^{2}$ each were prepared in accordance with the principles of the Braun-Blanquet school (1928), using the simplified Barkmann et al. scale (1964). Value 'rr' was assumed to be the smallest cover of species, corresponding to an area of about $0.01 \%$, while the limit value between ' $r$ ' and ' + ' was assumed to be a cover area of $0.5 \%$. No species occurring outside the phytosociological relevé area was recorded. Cover was used as the measure of abundance (Barkmann et al. 1964). Soil samples, from a depth of about $10 \mathrm{~cm}$ measured from the top of the mineral organic matter horizon, were taken from the central part of the phytosociological relevés for laboratory analyses. The soil samples were dried and divided. The skeletal and sand fractions were determined using the sieve method and compared using the PTG 2008 divisions (Polskie Towarzystwo Gleboznawcze 2009). The remaining part was sifted through a $1 \mathrm{~mm}$ diameter sieve. The content of organic matter in the upper soil level was determined by the loss on ignition method at $600^{\circ} \mathrm{C} ; \mathrm{pH}$ was measured using an electronic $\mathrm{pH}$-meter in a distilled water solution in a standard ratio of 10:25. Phytosociological data were subjected to arithmetic transformation (Tüxen, Ellenberg 1937). The order of the phytosociological relevés in the table was determined in relation to the main gradient of the results of the PCoA method with the Bray-Curtis distance measure, without additional transformations. The division of the relevés into groups was determined from the re- 
sults of the Ward classification (1963). The phytosociological relevés were interpreted on the basis of the studies by Matuszkiewicz (2008) and Kasprowicz (2010), taking into account the lack of an unequivocal diagnostic value of some of the vascular plant species that coexist in the Calamagrostio-Quercetum association as well as in mixed coniferous forests from the $\mathrm{Di}$ crano-Pinion alliance in central Poland. The next stage of the study was to determine the degree of similarity of the phytosociological relevés of typical acidophilous oak communities of Calamagrostio-Quercetum and the Dicrano-Pinion mixed coniferous forests. For this purpose, phytosociological relevés of the acidophilous oak forest association from Wielkopolska, compiled in five tables by Kasprowicz (2010), mixed coniferous forests from the southeastern part of the Mazowiecko-Podlaska Lowland (Sokołowski 1963), as well as mixed coniferous and acidophilous oak forest communities from the Kozienicka Forest (Zaręba 1971; Koba 2012, 2013) were used. A total of 14 tables (including 488 phytosociological relevés) were merged and then subjected to arithmetic transformation and Ward's classification. Numerical analyses were performed in PAST 3 software (Hammer et al. 2009). A map of the distribution of the association in central Poland was prepared using the ATPOL (Zając 1978) cartogram, after the mathematical correction of Komsta (2016). GIS work was performed using QGIS 3 software (QGIS Development Team 2019). The names of lichens were taken from Faltynowicz and Kossowska (2016), mosses from Ochyra et al. (2003), and vascular plants from Mirek et al. (2002).

\section{Results}

A map of the known sites of acidophilous oak forests in central Poland (Łódź and Mazovian Voivodeships) is presented in Figure 1. In the area of Łódź Voivodeship, the Calamagrostio-Quercetum community was recorded within 12 fields of the ATPOL cartogram, while in Mazowieckie Voivodeship -5 ones. The phytosociological relevés are presented in Table 1. Based on the Ward method of classification, a division into two groups of relevés was adopted. The first group (relevés 1-7) represents a typically formed community of Calamagro-

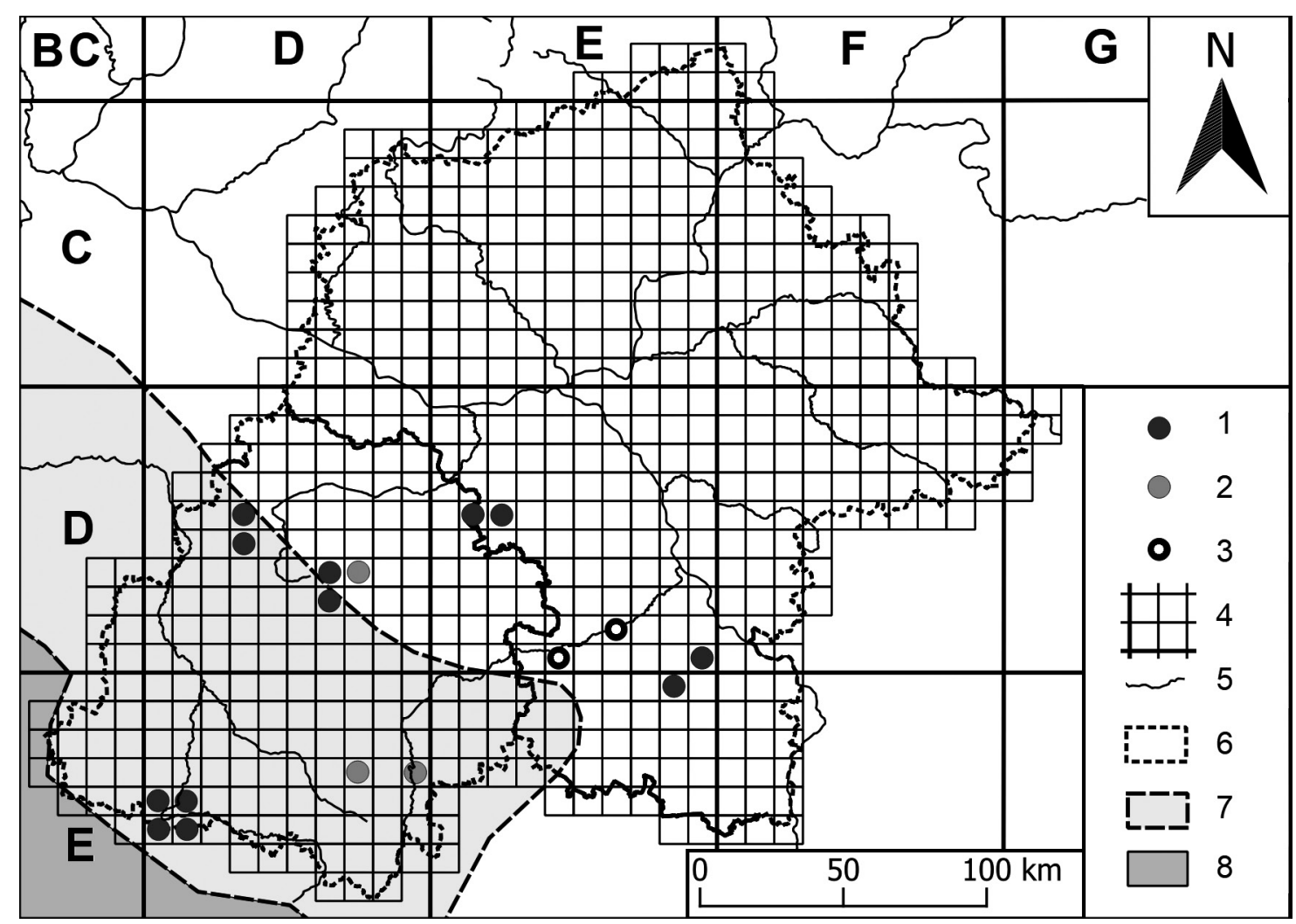

Figure 1. Location of stands of Calamagrostio-Quercetum association within eastern range limit (Łódź and Mazovian Viovodeships): 1 - stands with published relevé documentation, 2 - stands without relevé documentation, 3 - new stands in the vicinity of Kiedrzyn and Mikówka villages, 4 -ATPOL grid (Zając 1978; Komsta 2016), 5 - rivers, 6 - borders of voivodeships, 7 - ,provisional” association range - minor role in the landscape (Matuszkiewicz 1988; Matuszkiewicz, Matuszkiewicz 1996), 8 - main association range - moderate role in the landscape (Matuszkiewicz 1988, Matuszkiewicz, Matuszkiewicz 1996) 
Table 1. Differentiation of Calamagrostio-Quercetum within stands in the vicinity of Kiedrzyn and Mikówka villages (relevés 1-7 - typical aspect, 8-10 - aspect with higher share of Pinus sylvestris)

\begin{tabular}{lcccccccccc}
\hline Successive number of relevé & 1 & 2 & 3 & 4 & 5 & 6 & 7 & 8 & 9 & 10 \\
\hline Number of relevé & F3 & F2 & F109 & F105 & F108 & M1 & M2 & F1 & M4 & M3 \\
\hline Cover of upper tree layer A1 [\%] & 80 & 80 & 83 & 70 & 65 & 80 & 85 & 60 & 90 & 85 \\
\hline Cover of lower tree layer A2 [\%] & 0 & 0 & 0.5 & 1 & 2 & 5 & 10 & 20 & 0 & 10 \\
\hline Cover of tree layer in total A [\%] & 80 & 80 & 83 & 71 & 66 & 80 & 90 & 70 & 90 & 90 \\
\hline Cover of shrub layer B [\%] & 1 & 2 & 5 & 1 & 5 & 5 & 5 & 5 & 5 \\
\hline Cover of herb layer C [\%] & 25 & 20 & 30 & 30 & 55 & 70 & 65 & 30 & 50 & 65 \\
\hline Cover of moss layer D [\%] & 2 & 2 & 1 & 1 & 1 & 10 & 5 & 30 & 10 & 25 \\
\hline
\end{tabular}

D Ass*, Ch Ass** Calamagrostio-Quercetum (Kasprowicz 2010), Ch/D Cl. *** Quercetea robori-petraeae (Matuszkiewicz 2008)

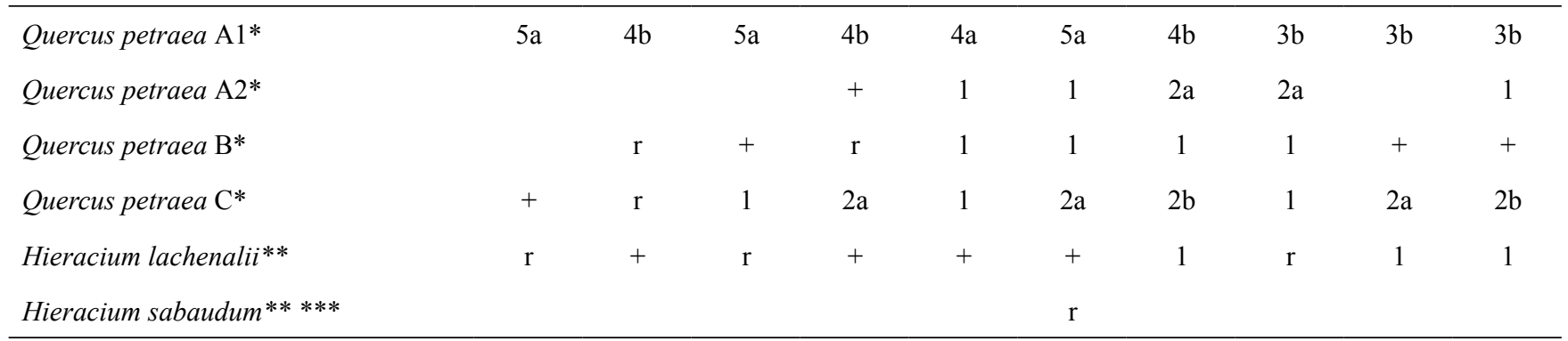

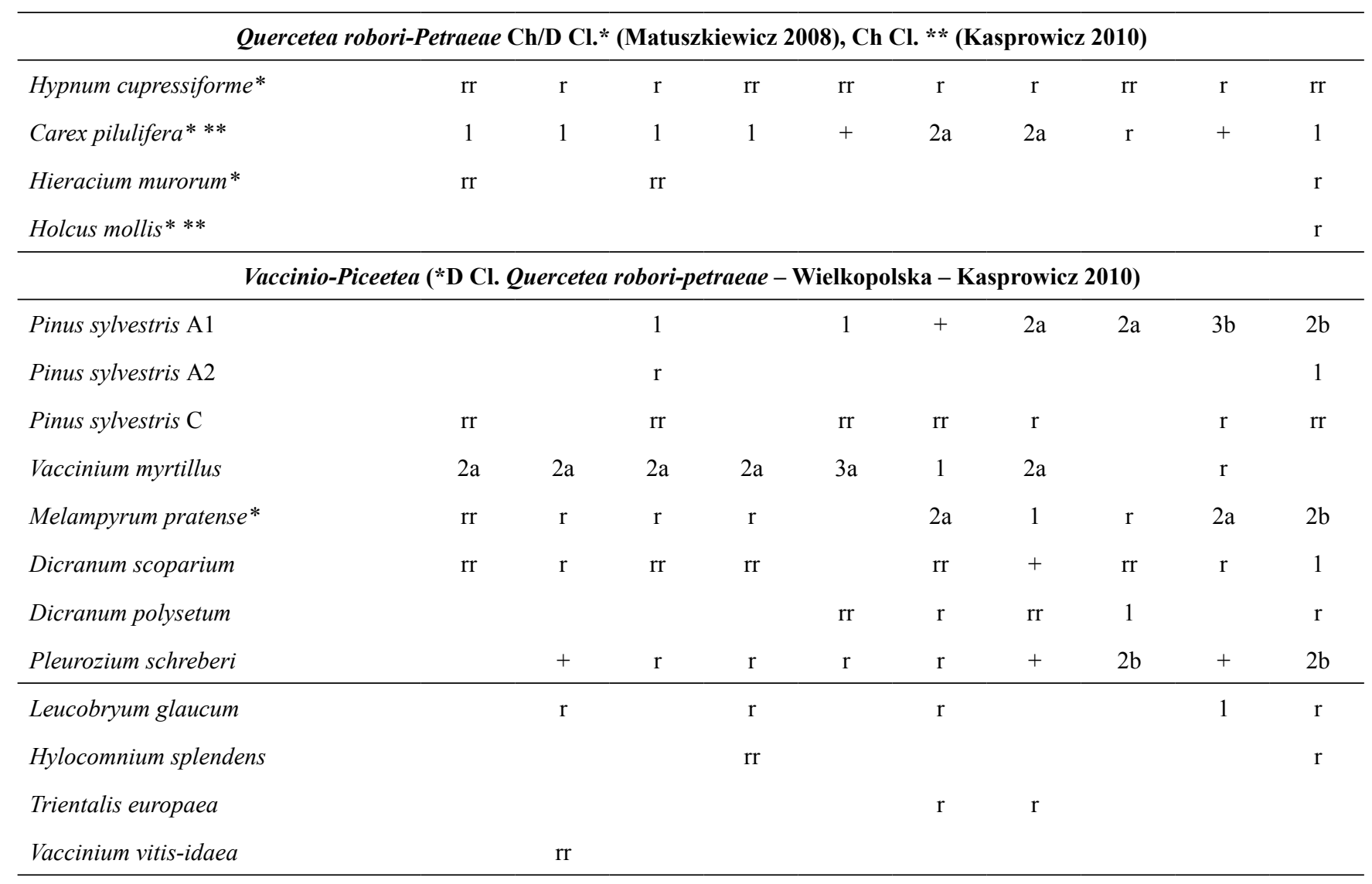




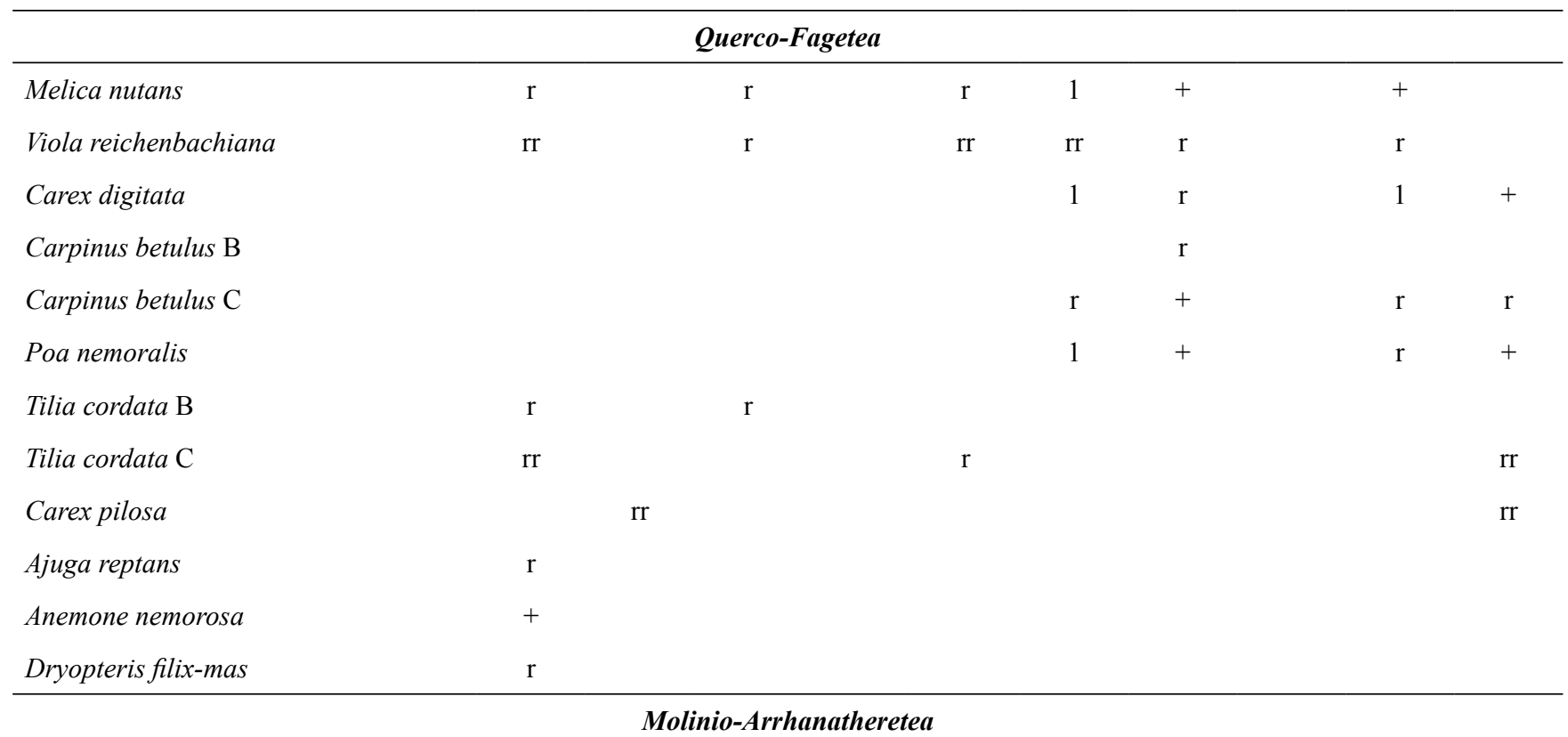

\section{Poa pratensis}

r

$+$

r

Carex hirta

Lotus corniculatus

Taraxacum sect. ruderalia

rr

\section{Nardo-Callunetea * et Koelerio-Corynephoretea **}

\section{Veronica officinalis*}

Agrostis capillaris*

Luzula campestris*

Pohlia nutans*

Viola canina*

Cladonia coniocraea*

Hieracium pilosella*

Ceratodon purpureus** rr

r

rr

rr

rr

rr $\mathrm{r}$

rr

rr

rr

r rr

r

r rr

r

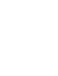

(n)

$\mathrm{r}$

rr $\quad \mathrm{rr}$

r

rr

r

rr

Trifolio-Geranietea * et Festuco-Brometea **

Polygonatum odoratum*

Peucedanum oreoselinum*

Sedum maximum $* *$

$\mathrm{r}$

rr

$+r$

r

r

rr

Clinopodium vulgare*

$\mathrm{r}$
1
$\mathrm{rr}$

rr

Epilobietea angustifolii

Betula pendula $\mathrm{A} 1$

1

$12 \mathrm{a}+$

Betula pendula $\mathrm{B}$

Betula pendula $\mathrm{C}$ r

$\begin{array}{llll} & r & r & \\ r & & + & r\end{array}$

$\mathrm{r}$

$\mathrm{r}$

r

$\mathrm{rr}$

rr

rr r

r

rr

rr rr rr 
Populus tremula A1

Populus tremula $\mathrm{C}$

Calamagrostis epigejos

$\mathrm{rr} \quad \mathrm{rr}$

rr

r

Fragaria vesca

$\mathrm{r}$

rr

r

Stellarietea * et Artemisietea **

Conyza canadensis*

rr

Fallopia convolvulus*

rr

Linaria vulgaris**

rr

Other

(*D. Ass. Calamagrostio-Quercetum, **D. Cl. Quercetea robori-petraeae - Wielkopolska - Kasprowicz 2010)

Festuca ovina*

Polytrichastrum formosum**

Pteridium aquilinum**

Calamagrostis arundinacea*

Hieracium umbellatum **

Quercus $x$ rosacea A1

Quercus $x$ rosacea A2

Quercus $x$ rosacea B

Quercus $x$ rosacea $\mathrm{C}$

Convallaria majalis

Frangula alnus B

Frangula alnus $\mathrm{C}$

Juniperus communis B

Sorbus aucuparia B

Sorbus aucuparia C

Luzula pilosa

Sciuro-hypnum oedipodium

Plagiomnium affine

Pyrus pyraster $\mathrm{C}$

Mycelis muralis

Rubus saxatilis

Maianthemum bifolium

Polytrichum juniperinum

Solidago virgaurea

Hypericum perforatum

Juniperus communis C

$\begin{array}{lll}1 & 1 \\ 1 & \mathrm{r} & \\ + & & 2 \mathrm{r} \\ + & \mathrm{r}\end{array}$

1

1

1

2a $2 \mathrm{a}$

$2 \mathrm{a}$

rr

+
$2 \mathrm{a}$
1

$\begin{array}{ccc}\mathrm{r} & 1 \\ 2 \mathrm{a} & 2 \mathrm{a} & 1 \\ + & 2 \mathrm{a} & + \\ \mathrm{r} & \mathrm{r}\end{array}$

\begin{tabular}{|c|c|}
\hline $2 \mathrm{a}$ & $2 \mathrm{a}$ \\
\hline 1 & \\
\hline 1 & $2 \mathrm{a}$ \\
\hline+ & \\
\hline
\end{tabular}

$2 \mathrm{~b}$

$\begin{array}{cc} & \\ & + \\ 1 & + \\ 2 \mathrm{a} & 1 \\ \mathrm{r} & \\ \mathrm{r} & \mathrm{rr} \\ & 1\end{array}$

$\begin{aligned} & \text { rr } \\ &+\quad \text { rr } \\ & \text { r }\end{aligned}$

rr

$\mathrm{rr}$

$+\frac{1}{+}+$

$1 \quad 1$

$2 \mathrm{~b}$

$2 \mathrm{a}$

1

1

$\begin{array}{cccccc}2 \mathrm{a} & 2 \mathrm{a} & 2 \mathrm{a} & 2 \mathrm{a} & + & \mathrm{rr} \\ + & + & \mathrm{r} & & 1 & + \\ \mathrm{r} & \mathrm{r} & \mathrm{r} & & + & \mathrm{r} \\ \mathrm{r} & & & \mathrm{r} & & \end{array}$

r +

r $\quad$ rr $\quad+$

$+$

rr

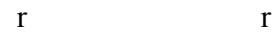

$\begin{array}{lll}r & r & r\end{array}$

r rr

rr $\quad \mathrm{r} \quad \mathrm{r}$

$+\quad 1$

rr

rr

r

$1-+$

$+\quad+1+$

$\mathrm{rr}$

$\mathrm{rr}$

$\mathrm{rr}$

rr

r

1

1 rr $\quad$ rr $\quad$ rr

$+$

$+\frac{100}{20}$

r rr

rr $\quad r$

r

rr

rr

rr

$\begin{array}{llll}\mathrm{r} & & \mathrm{r} \\ \mathrm{rr} & & \\ \mathrm{rr} & \mathrm{rr} & \end{array}$




\begin{tabular}{|c|c|c|c|c|}
\hline Moehringia trinervia & $\mathrm{rr}$ & $\mathrm{rr}$ & $\mathrm{r}$ & \\
\hline Dryopteris carthusiana & $\mathrm{rr}$ & & $\mathrm{rr}$ & \\
\hline Veronica chamaedrys & & + & + & \\
\hline Pimpinella saxifraga & & & $\mathrm{rr}$ & $\mathrm{rr}$ \\
\hline
\end{tabular}

stio-Quercetum, with the dominance of sessile oak Quercus petraea in the stand and a high proportion of Quercetea robori-petraeae species, including pill sedge Carex pilulifera. The second group (relevés 8-10) includes degenerated patches of the association, with an increased share of Pinus sylvestris in the stand and a higher coverage of red-stemmed feathermoss Pleurozium schreberi (Willd. ex Brid.) Mitt. in the moss layer. There is an almost complete absence of bilberry Vaccinium myrtillus visible within this group. The characteristics and selected soil parameters of the sites are presented in Table 2. The results of the analysis of similarity of the relevés to the acidophilous oak forests of Wielkopolska, mixed coniferous forests of the southeastern part of the Mazowiecko-Podlaska Lowland and mixed coniferous forests and acidophilous oak forests of the Kozienice Forest are presented in Table 3.

Sporadic species (group 'other'): Prunus insititia C 1 - rr; Carex ovalis 3 -r; Chamaecytisus ruthenicus 9 -r; Festuca trachyphylla 7 -r; Galeopsis bifida 3 -rr, Vincetoxicum hirundinaria 5 -r; Aulacomium androgynum 10 - rr; Brachytheciastrum velutinum 2 - rr; Dicranella heteromalla 6 - rr; Plagiothecium curvifolium 10 - rr; Plagiothecium denticulatum 9 - rr.

List of phytosociological relevés (coordinates given according to WGS 84):

1 - Grójec Forest District, Borowina Range, compartment $77 \mathrm{a}$, oak stand of the coppice origin, N: $51^{\circ} 35^{\prime} 13,6^{\prime \prime}$ E: $20^{\circ} 42^{\prime} 13,8^{\prime \prime}$.

2 - Grójec Forest District, Borowina, compartment $74 \mathrm{f}$, oak stand of the coppice origin, $\mathrm{N}: 51^{\circ} 35^{\prime} 18,2^{\prime \prime} \mathrm{E}$ : $20^{\circ} 42^{\prime} 01,7$ '”.

3 - Grójec Forest District, Borowina Range, a patch of an oak stand of the coppice origin in a pine stand, compartment 78d, N: $51^{\circ} 35^{\prime} 10.5^{\prime \prime}$ E: $20^{\circ} 41^{\prime} 53.7$ '.

4 - Grójec Forest District, Borowina Range, compartment $78 \mathrm{a}$, oak stand of the coppice origin, N: $51^{\circ} 35^{\prime} 15,1^{\prime}$ " E: $20^{\circ} 42^{\prime} 08,5^{\prime \prime}$.

5 - Grójec Forest District, Borowina Range, compartment $78 \mathrm{c}$, a patch of an oak stand of the coppice origin in a pine stand, N: $51^{\circ} 35^{\prime} 16,1^{\prime \prime} \mathrm{E}: 20^{\circ} 41^{\prime} 54,5^{\prime}$ ".

6 - Dobieszyn Forest District, Turno Range, compartment $69 \mathrm{f}$, a patch of an oak stand within a pine stand, N: 51³8'06.0" E: 2059'05.3”.
7 - Dobieszyn Forest District, Turno Range, compartment 73a, a patch of an oak stand within a pine stand, N: 513'05.7" E: $20^{\circ} 59^{\prime} 07.6$ ".

8 - Grójec Forest District, Borowina Range, compartment $78 \mathrm{~b}$, oak stand of the coppice origin, $\mathrm{N}$ : $51^{\circ} 35^{\prime} 16,8^{\prime \prime}$ E: $20^{\circ} 41^{\prime} 59,7^{\prime}$ '.

9 - Dobieszyn Forest District, Turno Range, compartment $73 \mathrm{a}$, a patch of an oak stand within a pine stand, N: 51'38'01.7" E: 2059'13.5".

10 - Dobieszyn Forest District, Turno Range, compartment $73 \mathrm{a}$, a patch of an oak stand within a pine stand, N: $51^{\circ} 38^{\prime} 00.6 " \mathrm{E}$ : $20^{\circ} 59^{\prime} 15.6 ”$.

\section{Discussion}

The phytosociological material includes relevés representing both typical (relevés 1-7) and degenerated (relevés 8-10) forms of the Calamagrostio-Quercetum association (Table 1). The typical form does not differ significantly from the acidophilous oak forest association from Wielkopolska (cf. Kasprowicz 2010). Phytosociological relevés representing it were combined with Calamagrostio-Quercetum relevés in group B (Table 3), and were distinguished from the phytosociological relevés representing mixed coniferous forests from the Dicrano-Pinion alliance. The degenerated form includes patches with a significant share of Scots pine Pinus sylvestris in the stand and a higher cover of red-stemmed feathermoss Pleurozium schreberi in the moss layer, but it still belongs to Calamagrostio-Quercetum, connected within the boundaries of group B with the relevés from Wielkopolska (Table 3). An artificially increased share of pine in deciduous forest communities is called pinetization and is described as a form of degeneration of forest communities (Olaczek 1972, 1974). In the case of the acidophilous oak forest, an increased share of pine in the stand is considered to be a distinguishing feature of the stands of this association in the eastern part of the range, as well as a possible form of degeneration associated with pine being favoured (Matuszkiewicz 2001; Matuszkiewicz 2008; Kasprowicz 2010; Matuszkiewicz et al. 2012).

When the first sites of acidophilous oak forests were discovered in Poland (Fabiszewski, Faliński 1964), the 
Table 2. Characteristic and selected parameters of soils within researched stands of Calamagrostio-Quercetum in the vicinity of Kiedrzyn and Mikówka villages (on the basis of BDL 2019 and carried out selected laboratory analyses)

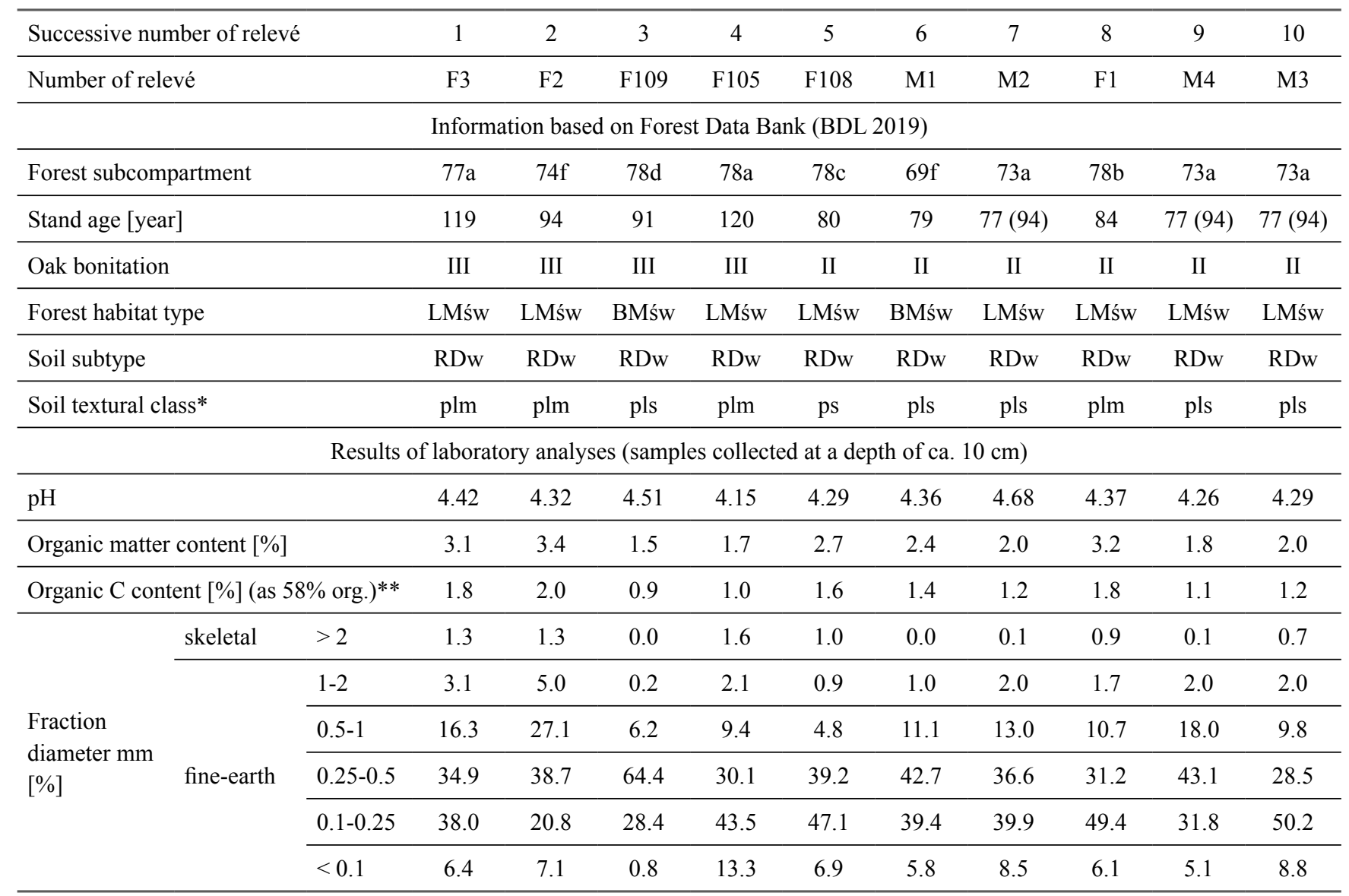

Forest habitat types: LMśw - fresh mixed deciduous forest, BMśw - fresh mixed coniferous forest; Soil subtype (Reference Soil Group): RDw - brunic arenosol (typical rusty soil),

* soil textural group: plm - (loose) sand with layers or aggregations of more loamy materials, pls - (weak loamy) sand, ps - (loose) sand

** value of $58 \%$ share of organic matter according to Nelson and Sommers (1982)

concept of degeneration and synanthropization of plant associations had just started to be developed (Faliński 1966, 1972; Olaczek 1972, 1974). For this reason, the correct classification of acidophilous oak forest patches, especially with anthropogenically introduced pine trees, was much more difficult (Wojterski et al. 1981; Kasprowicz 2010). Such communities were usually classified as Querco-Pinetum mixed coniferous forests (Kasprowicz 2010). For this reason, the eastern boundary of Calamagrostio-Quercetum association's range was only approximated (Matuszkiewicz 1988; Matuszkiewicz, Matuszkiewicz 1996). Zaręba (1988) postulated the distinction of acidophilous oak forests with pine in the northeastern parts of the sessile oak's range (including Mazovia). He proposed to take into account the division of mixed coniferous forests Pino-Quercetum (Kozł. 1925 em Mat. Et Pol. 1955) into two communities, by di- stinguishing the moist forms as Populo tremulae-Quercetum in the sense of Sokolowski $(1968,1980)$ and accepting them as a synonym for Querco-Pinetum proposed by Matuszkiewicz, and including Pino-Quercetum as acidophilous sessile oak forests with pine Quercetum sessiliflorae (petraeae?) -Pinetum. The author acknowledged that this community was not exactly the same as the acidophilous oak forest $\mathrm{Ca}$ lamagrostio-Quercetum petraeae, whose range boundaries were accepted to be in Pomerania and Wielkopolska. The relevés of acidophilous oak forests with pine, as presented in Zaręba's collective table (1988), came mainly from unpublished data, including those from the Kozienice Forest. The relevés of Zaręba's mixed coniferous forests (1971) used in the analysis, coming from this area, were largely combined with both Sokołowski's (1963) mixed coniferous forest communities and Kasprowicz's (2010) acidophilous oak 
Table 3. Comparison of similarity of carried out relevés to acidopilous oak forests from Wielkopolska (Kasprowicz 2010), mixed oak-pine forests from Mazowiecko-Podlaska Lowland (Sokołowski 1963) and oak-pine forests and acidophilous oak forests from Kozienicka Forest (Zaręba 1971; Koba 2012, 2013): A-F - groups distinguished by Wards classification, the numbers of relevés from the datasets were summarized

\begin{tabular}{|c|c|c|c|c|c|c|c|c|c|}
\hline No & Name of the dataset* & Author & A & $\mathrm{B}$ & $\mathrm{C}$ & $\mathrm{D}$ & $\mathrm{E}$ & $\mathrm{F}$ & $\mathrm{A}-\mathrm{F}$ \\
\hline 2 & $C-Q$ typicum (var. typ.) & Kasprowicz (2010) & 3 & 20 & 6 & 4 & 0 & 3 & 36 \\
\hline 3 & C-Q typicum (var. Anemone nemorosa) & Kasprowicz (2010) & 3 & 9 & 24 & 3 & 0 & 4 & 43 \\
\hline 4 & $C-Q$ polgonatetosum (var. typ.) & Kasprowicz (2010) & 26 & 40 & 3 & 9 & 0 & 0 & 78 \\
\hline 6 & Q-P typicum & Zaręba (1971) & 0 & 6 & 0 & 13 & 2 & 2 & 23 \\
\hline 7 & $Q-P$ berberidetosum & Zaręba (1971) & 0 & 1 & 0 & 10 & 2 & 1 & 14 \\
\hline 8 & Q-P populetosum (var. Typ.) & Zaręba (1971) & 0 & 0 & 1 & 3 & 4 & 1 & 9 \\
\hline 11 & $Q-P$ typicum & Sokołowski (1963) & 0 & 0 & 1 & 3 & 4 & 7 & 15 \\
\hline 12 & Q-P populetosum & Sokołowski (1963) & 0 & 4 & 2 & 2 & 21 & 19 & 48 \\
\hline 13 & $C-Q$ & Koba $(2012,2013)$ & 1 & 2 & 0 & 0 & 0 & 0 & 3 \\
\hline 14 & $C-Q$ & this study & 0 & 10 & 0 & 0 & 0 & 0 & 10 \\
\hline \multicolumn{3}{|c|}{$1-14$} & 49 & 136 & 110 & 63 & 47 & 83 & 488 \\
\hline \multicolumn{3}{|c|}{ Phytosociological interpretation* } & $C-Q$ & $C-Q$ & $C-Q$ & $\begin{array}{c}Q-P / \\
C-Q\end{array}$ & $\begin{array}{c}Q-P \& \\
S-P\end{array}$ & $\begin{array}{c}S-P \& \\
Q-P\end{array}$ & $\mathrm{X}$ \\
\hline
\end{tabular}

*C-Q-Calamagrostio-Quercetum, Q-P-Querco-Pinetum (=Pino-Quercetum), S-P-Serratulo-Pinetum.

forests. This indicates the transient nature of the communities presented above and/or the phenomenon of the pinetization of the Calamagrostio-Quercetum association in this area (Table 3). The presence of acidophilous oak forests in Kozienicka Forest is also supported by the combination of phytosociological relevés prepared by Koba (2012, 2013) documenting this association with a group of relevés of its Wielkopolska analogue (Table 3). On the basis of Zaręba's observations (1988) and comparisons (Table 3), it can be assumed that most likely, acidophilous oak forest patches in a degenerate form were found in southern Mazovia in the second half of the $20^{\text {th }}$ century. The phenomenon of pinetization may have been responsible for the difficulties in distinguishing them. Both Jakubowska-Gabara (1999) and Koba (2012) considered the locations of the acidophilous oak forests (Bolimowski Landscape Park and Kozienicka Forest) to be at the edge of their range. The patches of acidophilous oak forests recorded near the villages of Kiedrzyn and Mikówka are located in a zone between these sites. This may indicate a wider (at least $50-60 \mathrm{~km}$ to the east) range of this association in this region of Poland, compared to the assumed 'provisional' range. (cf. Matuszkiewicz 1988; Matuszkiewicz, Matuszkiewicz 1996).

The two main syntaxonomic depictions of acidophilous oak forests in Poland differ slightly from each other (cf. Matuszkiewicz, Matuszkiewicz 1996; Kasprowicz 2010), which is mainly due to the different boundaries of the areas of these studies. In spite of this, the analysed patches of the communities undoubtedly belong to the Calamagrostio arundinaceae-Quercetum petraeae association (Table 3), depicted by both approaches in a similar way. A number of species characteristic and differential for acidophilous oak forests were recorded in the patches (Table 1), including Carex pilulifera and several species of the genus Hieracium. In comparison with Kasprowicz's compilation (2010), the analysed patches are most similar to the Wielkopolska variety, which is related to a small share of Lathyrus montanus Bernh., Fagus sylvatica L. and Deschampsia flexuosa, and in the case of the analysed site - even their absence, as well 
as the absence of species with a southern range. The relatively large cover of Festuca ovina in the undergrowth indicates the similarity of the noted patches to the Calamagrostio-Quercetum festucetosum subassociation distinguished in the Lagiewnicki Forest (NE outskirts of Łódź) (Kurowski 2009). A characteristic feature of the studied sites is also the occurrence of species considered to be associated with mixed coniferous forests (Matuszkiewicz 2008), such as: Carex digitata L., Carpinus betulus L., Mycelis muralis (L.) Dumort. or Rubus saxatilis $\mathrm{L}$.

The examined patches of Calamagrostio-Quercetum are located in habitats defined in the Forest Data Bank (BDL 2019) as fresh mixed deciduous (8 phytosociological relevés) and fresh mixed coniferous ( 2 relevés). Thus, the habitat range is almost identical to the previously reported range from Wielkopolska (Lasota et al. 2005; Rutkowski, Maciejewska -Rutkowska 2007), as well as the regions of the lake districts, uplands and highlands of western Poland (Lasota 2013). Moreover, acidophilous oak forest sites were recorded in a fresh mixed forest habitat in Kozienicka Forest (Koba 2012, 2013).

In the sites near Kiedrzyn and Mikówka villages, the superficial deposits studied at a depth of about $10 \mathrm{~cm}$ had the character of loose sands (in situ organoleptic evaluation). They were characterized by a predominance of medium and fine sand content (Table 2). According to the Forest Management Plan (FMP) for the Grójec and Dobieszyn Forest Districts, these patches were located mainly on deposits of loose and weak loamy sands, loose sands with layers or aggregations of more loamy material and less often, weak loamy sands (BDL 2019). Such differentiation belongs to more frequently recorded granulometric compositions of Calamagrostio -Quercetum in Wielkopolska, for example, in the Zielonka Experimental Forest District (Rutkowski, Maciejewska-Rutkowska 2007). Similar granulometric compositions were also recorded in acidophilous oak patches in the habitats of the fresh mixed coniferous forest and fresh mixed deciduous forest in the Jarocin and Czerniejewo Forest Districts (Lasota et al. 2005). The presence of loamy sands deposited on weak loamy and loose sands, as well as loose sands on deeply deposited till, were noted in the acidophilous oak stands in Kozienicka Forest (Koba 2012, 2013). Mixed coniferous forests occur most frequently on river or fluvio-glacial sands, with sites of dunes having a grain size corresponding to strongly permeable deep loose sands or weak loamy sands on loose sands (Matuszkiewicz 2001; Lasota 2013). Acidophilous oak forests, however, are usually recorded in areas of glacial or sandstone formations deposited in the immediate vicinity of the glacier margin, with different grained formations such as loose and weak loamy sands overlaid or lined with clay sands or even clay (Matuszkiewicz 2001; Lasota 2013). The soils of acidophilous oak forests are usually slightly richer (Lasota 2013). The analysed sites are located within the range of loose, weak loamy sands, often with layers or aggregations of more loamy materials (Table 2), which to some extent may indicate that the substrate is slightly more suitable for acidophilous oak forests than for mixed coniferous forests.

The acidophilous oak forest sites near Kiedrzyn and Mikówka villages are characterized by the occurrence of brunic arenosols (typical rusty soils) (RDw, Table 1), in some places with visible signs of podzolization (in situ studies). Typical rusty soils (RDw) and brown rusty soils (RDbr) were found at the sites located in the Kozienicka Forest (Koba 2012, 2013). Similarly, in Wielkopolska, brown rusty soils, typical rusty soils and podzolic rusty soils were found in the acidophilous oak forest sites, although in some places haplic luvisols (cutanic), brown haplic luvisols and umbric gleysols (arenic) or gleyic umbrisols (arenic) were also found (Lasota et al. 2005; Rutkowski, Maciejewska-Rutkowska 2007). In other parts of western Poland, rusty soils also dominate in acidophilous oak forests, and brown and podzolic soils are also recorded relatively often (Lasota 2013).

In central Wielkopolska (in the Jarocin and Czerniejewo Forest Districts), the $\mathrm{pH}$ of the upper soil horizons in fresh mixed coniferous habitat was about 3.3-4.1, while the organic carbon content was between 1.57 and $5.04 \%$. On the other hand, the patches of acidophilous oak forest in the fresh mixed deciduous habitat had a pH of the upper soil horizon from 3.6 to 4.1 and an organic carbon content from 1.66 to $5.36 \%$. (Lasota et al. 2005). As the average share of carbon in organic matter is about $58 \%$ (Nelson, Sommers 1982), therefore the organic carbon content at a depth of about $10 \mathrm{~cm}$ in the examined patches was from 0.9 to $2.0 \%$. This value is slightly lower than in the case of central Wielkopolska, as well as other areas of acidophilous oak forests in western Poland (Lasota 2013). The studied patches are also characterized by a higher $\mathrm{pH}$, in the range of 4.15 to 4.68 , which is comparable to the $\mathrm{pH}$ of the upper soil horizons in the acidophilous oak forest sites studied in western Poland by Lasota (2013). The observed differences are likely caused by a slightly higher depth of the soil samples taken from the sites near Kiedrzyn and Mikówka villages, compared to the analogous upper soil horizons of sites from central Wielkopolska.

\section{Summary of results and conclusions}

1) The patches of oak forests recorded near Kiedrzyn and Mikówka villages, situated in the southern part of Mazovia Voivodeship, belong to the Calamagrostio arundinaceae -Quercetum petraeae association; the habitat conditions of the analysed patches as well as the oak site index are analogous to sites of that association in other parts of Poland.

2) The patches from the Bolimowska and Kozienicka Forests, which the authors of cited studies considered to be at the 'border' of this association's range, are outside the 'provisional' range designated for this association in this part of 
Poland; the patches recorded near Kiedrzyn and Mikówka villages can be treated as a 'link' between the sites noted above.

3) The range of the Calamagrostio-Quercetum association is at least several dozen kilometres wider than the assumed 'provisional' range, reaching deeper into the southern part of the Mazovian Voivodeship.

\section{Conflict of interest}

The authors declare that there are no potential conflicts of interest.

\section{Funding sources}

The research at the site near Kiedrzyn village was financed by the Institute of Forest Sciences of Warsaw University of Life Sciences-SGGW (505-10-031100-P00571-99).

\section{References}

Andrzejewski H., Kurowski J.K. 2001. Charakterystyka fitocenotyczna rezerwatu Las Łagiewnicki, w: Kurowski J.K. (red.). Szata roślinna Lasu Łagiewnickiego w Łodzi. Urząd Miasta Łódź, Uniwersytet Łódzki, Łódź, 109-122. ISBN 83-909439-5-6.

BDL 2019. Bank Danych o Lasach. https://www.bdl.lasy.gov.pl/ portal/mapy\# [10.10.2019].

Barkmann J.J., Doing H., Segal S. 1964. Kritische Bemerkungenund Vorschlägezurquantitativen Vegetationsanalyse. Acta Botanica Neerlandica 13: 394-419. DOI 10.1111/j.14388677.1964.tb00164.x.

Braun-Blanquet J. 1928. Pflanzensoziologie. Grundzüge der Vegetationskunde. Biologische Studienbücher 7.

Brzeg A., Kasprowicz M., Krotoska T. 2001. Acidofilne lasy klasy Quercetea robori-petraeae Br.-Bl. et R.Tx. 1943 nom. mut. w Wielkopolsce. Cz. III. Calamagrostio arundinaceae-Quercetum petraeae (Hartmann 1934) Scamoni et Passarge 1959 em. Brzeg et al. 1989 - środkowoeuropejska kwaśna dąbrowa trzcinnikowa. Badania Fizjograficzne nad Polska Zachodnia, Ser. B 50: 41-61.

BULiGL 2017. Program ochrony przyrody. Plan urządzenia lasu dla Nadleśnictwa Przedbórz na lata 2017-2016 wg stanu lasu w dniu 1 stycznia 2017. Biuro Urządzania Lasu i Geodezji Leśnej, Oddział w Warszawie, 1-157.

Cabała S. 1990. Zróżnicowanie i rozmieszczenie zbiorowisk leśnych na Wyżynie Śląskiej. Prace Naukowe Uniwersytetu Ślaskiego, Ser. Biologia 1068: 5-142.

Celiński F., Wika S. 1978. Próba nowego spojrzenia na stosunki fitosocjologiczne rezerwatu „Parkowe” w Złotym Potoku koło Częstochowy. Fragmenta Floristica et Geobotanica, Ser. Polonica 24(2): 277-307.

Fabiszewski J., Faliński J.B. 1964. O roślinności okolic Przemętu. Przyroda Polski Zachodniej 8(1-4): 23-45.

Faliński J.B. 1966. Próba określenia zniekształceń fitocenozy. System faz degeneracyjnych zbiorowisk roślinnych. Ekologia Polska 12: 31-42.
Faliński J.B. 1972. Synantropizacja szaty roślinnej - próba określenia istoty procesu i głównych kierunków badań. Phytocoenosis 1(3): 157-170.

Fałtynowicz W., Kossowska M. 2016. The lichens of Poland. A fourth checklist. Acta Botanica Silesiaca Monographiae 8: 1-122.

Goncharenko I.V., Yatsenko H.M. 2020. Phytosociological study of the forest vegetation of Kyiv urban area (Ukraine). Hacquetia 19(1): 99-126. DOI 10.2478/hacq-2019-0012.

Greń C., Wika S. 2009. Ciepłolubny podzespół środkowoeuropejskiej kwaśnej dąbrowy trzcinnikowej Calamagrostio arundinaeceae - Quercetum petraeae polygonatetosum odorati Passarge in Pallas 1996 na Wyżynie Śląsko-Krakowskiej. Badania Fizjograficzne nad Polską Zachodnia, Ser. B - Botanika 58: 7-17.

Hammer Ø., Harper D.A.T., Ryan P.D. 2001. PAST: Paleontological statistics software package for education and data analysis. Paleontologia Electronica 4(1): 9.

Hartmann F.K. 1934. Zur soziologisch-ökologischen Kenzeichnung der Waldbestände in Norddeutschland. Forstliche Wochenschwift Silva 22(18): 137-144.

Hereźniak J. 1993. Stosunki geobotaniczno-leśne północnej części Wyżyny Śląsko-Krakowskiej na tle zróżnicowania i przemian środowiska. Monographiae Botanicae 75: 3-368. DOI 10.5586/mb.1993.001.

Jakubowska-Gabara J. 1999. Roślinność leśna Bolimowskiego Parku Krajobrazowego. Monographiae Botanicae 85: 27-98. DOI 10.5586/mb.1999.002.

Kamionka S. 1971. Zespoły leśne środkowej części dorzecza Lutyni (południowa Wielkopolska). Prace Komisji Biologicznej PTPN 34(2): 1-54.

Kasprowicz M. 2010. Acidophilous oak forests of the Wielkopolska region (West Poland) against the background of Central Europe. Biodiversity: Research and Conservation 20: 1-138. DOI 10.2478/v10119-010-0012-4.

Kiedrzyński M., Kurowski J.K. 2013. Dąbrowy w Marianku, w: Kurowski J.K. (red.). Obszary Natura 2000 w województwie łódzkim. RDOŚ w Łodzi, Uniwersytet Łódzki, 120-121. ISBN 978-83-934396-1-4.

Koba J. 2012. Kresowe stanowisko środkowoeuropejskiego acydofilnego lasu dębowego Calamagrostio arundinaceae-Quercetum petraeae (Hartm. 1934) Scam. et Pass. 1959 na terenie Kozienickiego Parku Krajobrazowego. Parki Narodowe i Rezerwaty Przyrody 31(3): 13-21.

Koba J. 2013. Pierwsze stanowisko widlicza (widłaka) spłaszczonego Diphasiastrum complanatum (L.) Holub na terenie Kozienickiego Parku Krajobrazowego. Parki Narodowe i Rezerwaty Przyrody 32(3): 75-77.

Komsta Ł. 2016. Rewizja matematyczna siatki geobotanicznej ATPOL - propozycja algorytmów konwersji współrzędnych. Agronomy Science 71(1): 31-37.

Krotoska T., Piotrowska H. 1962. Dąbrowy na glebach „typu krotoszyńskiego". Badania Fizjograficzne nad Polska Zachodnia 10: 133-185.

Kuczyńska I. 1973. Stosunki geobotaniczne Opolszczyzny. Zbiorowiska leśne. Acta Universitatis Wratislaviensis 162, Prace Botaniczne 15: 1-91. 
Kurowski J.K. 1998. Lasy, w: Kurowski J.K. (red.). Park Krajobrazowy Wzniesień Łódzkich. Eko-Wynik, Łódź, 39-52. ISBN 83-87017-05-1.

Kurowski J.K. 2009. Roślinność leśna, w: Kurowski J.K. (red.) Szata roślinna Polski środkowej. Wyd. Eko-Graf, Łódź, 103123. ISBN 978-83-61354-13-0.

Kurowski J.K. i Andrzejewski H. 2013. Buczyna Janinowska, w: Kurowski (red.) Obszary Natura 2000 w województwie łódzkim. RDOŚ w Łodzi, Uniwersytet Łódzki, 90-93. ISBN 978-83-934396-1-4.

Kwiatkowski P. 1995. Szata roślinna projektowanego rezerwatu leśnego „Wąwóz Lipy” na Pogórzu Kaczawskim (Sudety Zachodnie). Ochrona Przyrody 52: 167-184.

Lasota J. 2013. Siedliskowo-florystyczna analiza środkowoeuropejskiego acydofilnego lasu dębowego (Calamagrostio arundinaceae-Quercetum petraeae [Hartm. 1934], Scam. et Pass. 1959). Zeszyty Naukowe UR w Krakowie, seria Rozprawy 393: 5-143.

Lasota J., Karp M., Biskup S. 2005. Siedliska kwaśnej dąbrowy trzcinnikowej (Calamagrostio arundinaceae-Quercetum petreae) w środkowej Wielkopolsce. Acta Scientiarum Polonorum Silvarum Colendarum Ratio et Industria Lignaria 4(1): 23-39.

Matuszkiewicz J.M. 1988. Przegląd fitosocjologiczy zbiorowisk leśnych Polski. Bory mieszane i kwaśne dąbrowy. Fragmenta Floristica et Geobotanica, Ser. Polonica 33(1-2): 107-190.

Matuszkiewicz J.M. 2001. Zespoły leśne Polski. Wydawnictwo Naukowe PWN, Warszawa, 376 s. ISBN 83-01-14555-2.

Matuszkiewicz W. 2008. Przewodnik do oznaczania zbiorowisk roślinnych Polski (synteza). Wydawnictwo Naukowe PWN. Warszawa, 537 s. ISBN 978-83-01-14439-5.

Matuszkiewicz W., Matuszkiewicz J.M. 1996. Przegląd fitosocjologiczny zbiorowisk leśnych Polski. Phytocoenosis 8: 1-79.

Matuszkiewicz W., Sikorski P., Szwed W., Wierzba M. (red.) 2012. Lasy i zarośla. Wydawnictwo Naukowe PWN, Warszawa, 1-518. ISBN 978-83-01-17064-6.

Mirek Z., Piękoś-Mirkowa H., Zając A., Zając M. 2002. Flowering plants and pteridophytes of Poland - a checklist [Krytyczna lista roślin naczyniowych Polski]. Instytut Botaniki im. Władysława Szafera Polskiej Akademii Nauk, Kraków, 1-442, ISBN 83-85444-83-1.

Nelson D.W., Sommers L.E. 1982. Total carbon, organic carbon, and organic matter, w: Page A.L. (red.) Methods of Soil Analysis, Part 2 - Chemical and Microbiological Properties, 2nd edn. American Society of Agronomy, Soil Science Society America, Madison, 539-579. ISBN 0-89118-072-9.

Ochyra R., Bednarek-Ochyra H., Żarnowiec J. 2003. Census catalogue of Polish mosses [Katalog mchów Polski]. Instytut Botaniki im. Władysława Szafera Polskiej Akademii Nauk, Kraków, 1-372. ISBN 83-85444-84-X.

Olaczek R. 1972. Formy antropogenicznej degeneracji leśnych zbiorowisk roślinnych w krajobrazie rolniczym Polski niżowej. Wydawnictwo Uniwersytetu Łódzkiego, Łódź, 1-170.

Olaczek R. 1974. Kierunki degeneracji fitocenoz leśnych i metody ich badania. Phytocoenosis 3: 179-190.

Olaczek R. 1986. Roślinność leśna Załęczańskiego Parku Krajobrazowego. Acta Universitatis Lodziensis, Folia Sozologica 2: 393-470.
Polskie Towarzystwo Gleboznawcze 2009. Klasyfikacja uziarnienia gleb i utworów mineralnych - PTG 2008. Roczniki Gleboznawcze 60(2): 5-16.

QGIS Development Team 2019. QGIS Geographic Information System. Open Source Geospatial Foundation Project. http:// qgis.osgeo.org [2.11.2019].

Rutkowski P., Maciejewska-Rutkowska I. 2007. Zróżnicowanie siedliskowe lasów dębowych w Nadleśnictwie Doświadczalnym Zielonka, w: P. Rutkowski (red.). Hodowla dębów w Polsce. Wybrane zagadnienia. Idee Ekologiczne 16: 121-133.

Scamoni A. 1961. Der märkische Kiefern-Traubeneichenwald ( $\mathrm{Ca}$ lamagrostio-Quercetum) als pflanzengeographische Erscheinung. Archiv für Forstwesen 10(3): 270-307.

Socha G. (red.) 2011. Rezerwaty Przyrody Województwa Łódzkiego. RDOŚ w Łodzi. 200 s. ISBN 978-83-934396-0-7.

Sokołowski A.W. 1963. Zespoły leśne południowo-wschodniej części Niziny Mazowiecko-Podlaskiej. Monographiae Botanicae 16: 3-176.

Sokołowski A.W. 1968. Zespoły leśne nadl. Zwierzyniec w Puszczy Białowieskiej. Prace Instytutu Badawczego Leśnictwa 354.

Sokołowski A.W. 1980. Zbiorowiska leśne północno-wschodniej Polski. Monographiae Botanicae 60. DOI 10.5586/ mb.1980.002.

Tüxen R., Ellenberg H. 1937. Der systematische und ökologische Gruppenvert. Ein Beitrag zur Begriffsbildung und Methodik der Pflanzensoziologie. Mitteilungen der Floristisch Soziologischen Arbeitsgemeinschaft 3: 171-84.

Ward J.H. 1963. Hierarchical grouping to optimize an objective function. Journal of the American Statistical Association 58: 236-244. DOI 10.1080/01621459.1963.10500845.

Wojterski T., Wojterska H., Wojterska M. 1981. Potencjalna roślinność naturalna dorzecza Baryczy (mapa 1:200 000). Polskie Przedsiębiorstwo Wydawnictw Kartograficznych, Wrocław.

Zając A. 1978. Atlas of distribution of vascular plants in Poland (ATPOL). Taxon 27(5/6): 481-484. DOI 10.2307/1219899.

Zaręba R. 1971. Badania geobotaniczne i fitosocjologiczne zespołów leśnych Puszczy Kozienickiej i Okręgu Radomsko-Kozienickiego. Zeszyty Naukowe Szkoły Gtównej Gospodarstwa Wiejskiego w Warszawie. Rozprawy Naukowe 11: 1-167.

Zaręba R. 1988. Dąb szypułkowy i dąb bezszypułkowy - ich naturalne występowanie w zespołach leśnych i typach siedliskowych lasu. Prace Instytutu Badawczego Leśnictwa, seria B 684: 129-178.

\section{Contribution of the authors}

P.Z. - concept, field work, laboratory analyses, data preparation for numerical analyses, numerical analysis, map development, literature review, manuscript writing;

W.C. - field work, laboratory analyses, moss identification, data preparation for numerical analyses, literature review, manuscript writing;

K.M. - laboratory analyses, literature review, data preparation for numerical analyses, manuscript writing. 